\title{
Metaplastic Carcinoma with Osteoclast like Giant Cells in the Breast
}

\author{
Sneha M. ${ }^{1}$, Guvera Vasireddy², Triveni Bhopal ${ }^{3}$ \\ ${ }^{1}$ Department of Pathology, Osmania Medical College, Koti, Hyderabad, Telangana, India. \\ ${ }^{2}$ Department of Pathology, Osmania Medical College, Koti, Hyderabad, Telangana, India. \\ ${ }^{3}$ Department of Pathology, Osmania Medical College, Koti, Hyderabad, Telangana, India.
}

\section{INTRODUCTION}

Metaplastic Carcinoma Breast is a distinct pathological entity as classified by WHO. It is an aggressive tumour with lower incidence of axillary lymph node involvement. They are usually triple negative and hence carry poor prognosis. It is Metaplastic due to transformation of epithelial component into non-glandular component, such as spindle cells, squamous cells or heterogenous elements.

Metaplastic carcinoma with osteoclast like giant cells in breast is rare and interesting entity comprising of $0.5-1.2 \%$ of breast carcinomas annually. Histologically it is poorly differentiated heterogenous tumour containing ductal carcinoma cells admixed with areas of spindle, squamous, chondroid or osseous elements. They are usually triple negative and hence carry poor prognosis. We present a case report of a 30-year-old female who presented with a well-defined solitary breast lump of $3.5 \times 3.5 \mathrm{~cm}$ with no axillary lymphadenopathy. A diagnosis of malignant phyllodes tumour was made and patient underwent simple mastectomy.

\section{PRESENTATION OF CASE}

A 30-year-old female presented with chief complaint of a swelling in the right breast since 2 months. On palpation a swelling of $3 \times 3 \mathrm{~cm}$ was present in the upper inner quadrant of right breast. A horizontal scar was seen over its surface. There was no axillary lymphadenopathy.

\section{Investigations}

- Ultrasound - USG right breast-evidence of ill-defined irregular marginal lobulated hyperechoic mass with increased vascularity noted in 2 o clock position in upper inner quadrant.

- USG left breast, both axilla -normal.

- Impression - f/s/o BIRADS $4 \mathrm{C}$ lesion in right breast.

- FNAC- highly cellular smear studied showed many irregular 3 dimensional sheets of tumour cells with oval to spindle nuclei with dark chromatin, mild pink cytoplasm and haemorrhage in background.

- Impression - features suggestive of malignant phyllodes tumour.

\section{PATHOLOGICAL DISCUSSION}

\section{Gross Examination}

Received grey white soft tissue mass measuring $13 \times 8 \times 5 \mathrm{~cm}$. Cut section showed a grey white area measuring $3 \times 2 \times 1 \mathrm{~cm}$, multiple bits were taken from the tumour and adjacent areas.
Corresponding Author: Dr. Sneha $M$,

Flat No. 202, SLN Arcade-2, Plot No. 14, Haripuri Colony, Road No. 5, Kothapet,

Hyderabad, Telangana, India.

E-mail: snehamed10@gmail.com

DOI: $10.14260 / \mathrm{jemds} / 2020 / 333$

Financial or Other Competing Interests: None.

How to Cite This Article:

Sneha M, Vasireddy G, Bhopal T. Metaplastic carcinoma with osteoclast like giant cells in the breast. J. Evolution Med. Dent. Sci. 2020;9(18):1525-1527, DOI: $10.14260 / \mathrm{jemds} / 2020 / 333$

Submission 09-08-2019,

Peer Review 25-12-2019,

Acceptance 02-01-2020,

Published 04-05-2020.

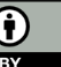




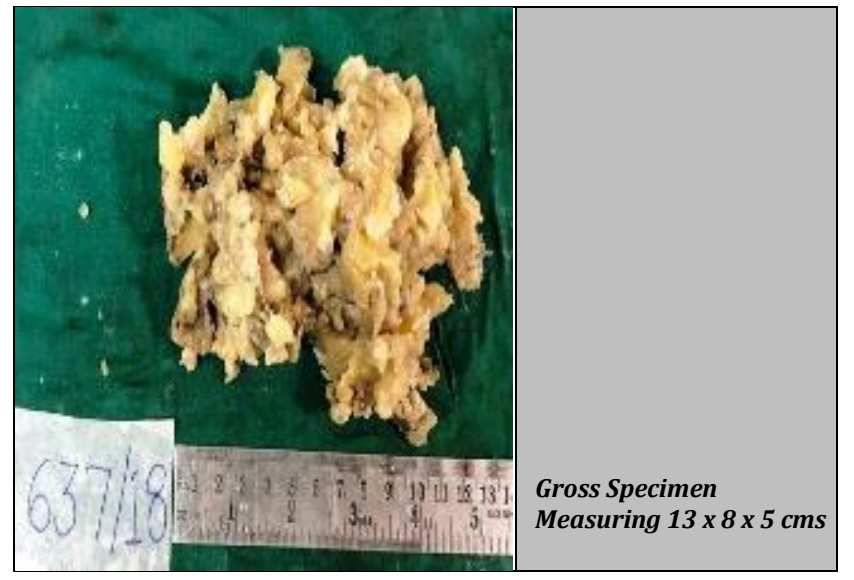

\section{Histopathologic Examination}

Revealed an invasive tumour tissue composed of plump to spindle shaped cells, highly hyper chromatic pleomorphic bizarre nuclei, numerous osteoclast like giant cells, areas of haemorrhage and necrosis along with metaplastic bony trabeculae, Sparse epithelial component. Prominent adenosis, hyalinization and fibrosis seen in adjacent breast parenchyma.

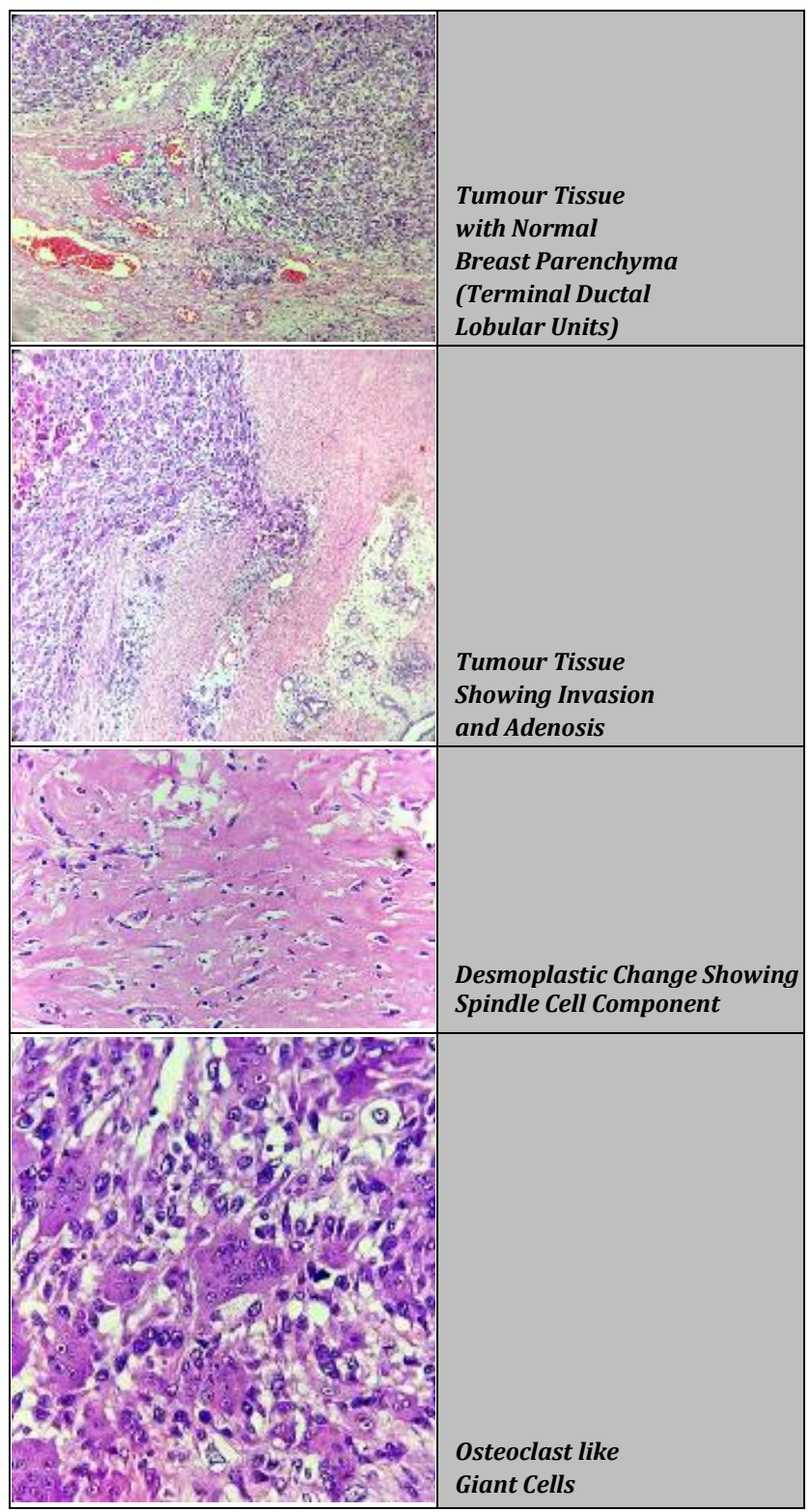

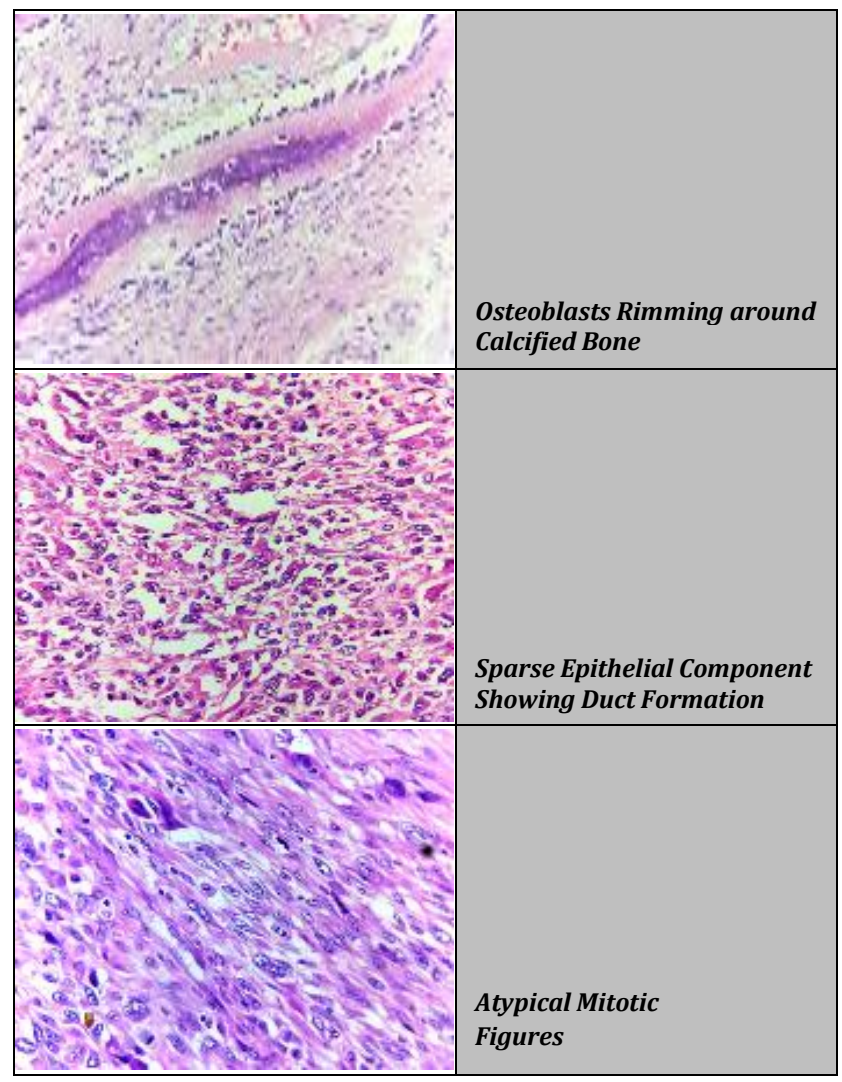

\section{Immunohistochemistry}

CK 5/6 positive, Vimentin positive, p63 positive in osteoclast like giant cells, CK7 negative ER negative PR negative and HER 2 neu negative.

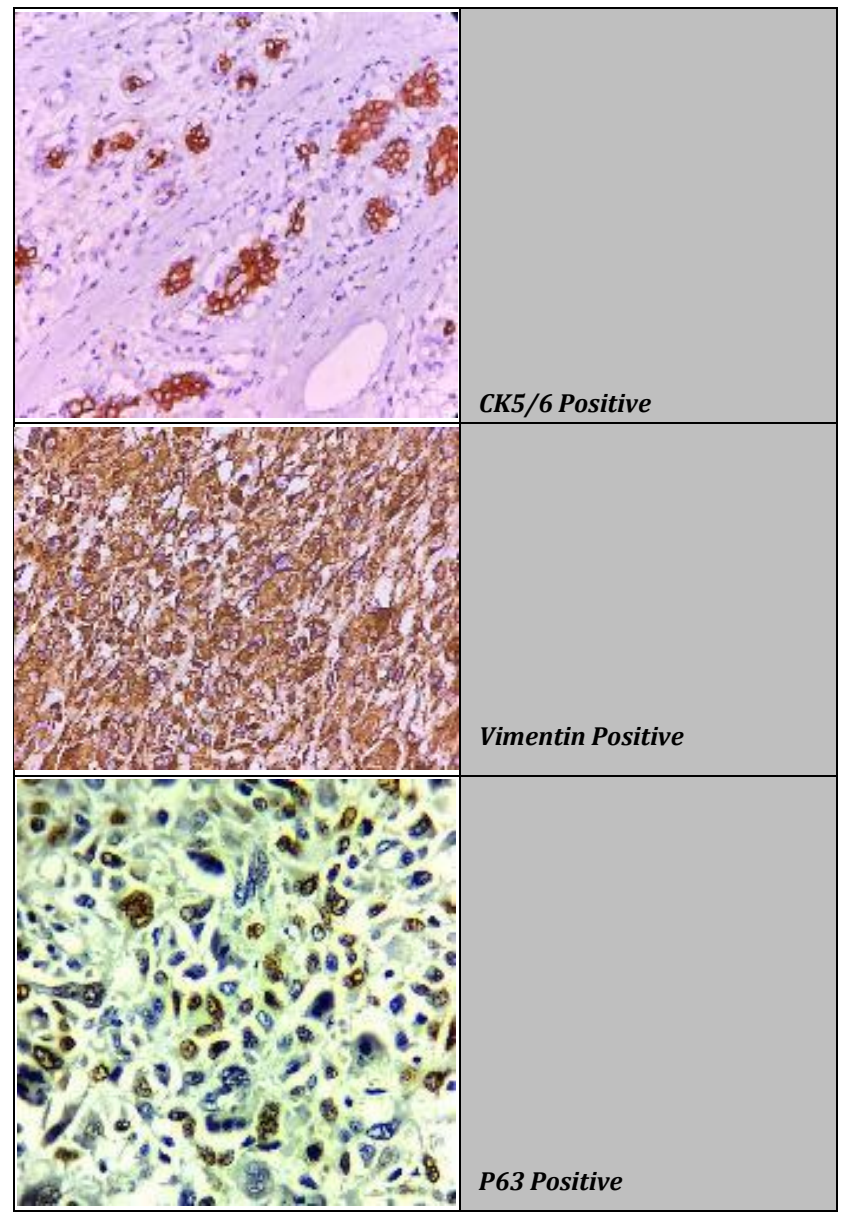




\section{DISCUSSION}

MCB is a rare tumour comprising of $<2 \%$ of breast carcinomas annually.1,2 The term metaplastic carcinoma was first introduced by Huvos et al. Breast carcinoma with osteoclastlike giant cells was first described by Rosen in $1979 .{ }^{3}$ Histologically it is poorly differentiated heterogenous tumour containing ductal carcinoma cells admixed with areas of spindle, squamous, chondroid or osseous elements

\section{WHO Classification of MCB4}

Epithelial

1. Squamous cell carcinoma.

2. Adenocarcinoma with spindle cell differentiation.

3. Aden squamous differentiation.

\section{Mixed}

1. Carcinoma with chondroid metaplasia.

2. Carcinoma with osseous metaplasia.

3. Carcinosarcoma.

\section{Wargotz \& Norris Classification of $\mathrm{MBC}^{5}$}

1. Spindle cell subtype.

2. Squamous cell carcinoma.

3. Carcinosarcoma.

4. Matrix producing subtype.

5. MBC with osteoclast like giant cells.

\section{TSE et al Classification of MBC6}

- Epithelial only carcinoma.

- Biphasic epithelial \& sarcomatoid carcinoma.

- Monophasic spindle cell carcinoma.

\section{Oberman Classification of $\mathrm{MBC}^{7}$}

- Spindle cell carcinoma.

- Invasive ductal carcinoma with extensive squamous metaplasia.
- Invasive carcinoma with pseudosarcomatous metaplasia.

\section{CONCLUSIONS}

- We conclude that this case of MBC showed osteoclast like giant cells along with bone which is very rare in occurrence.

- MBCs are basal like breast cancers with worst prognosis.

- Pathological classification has no clinical significance and MBCs should be considered as one entity.

\section{REFERENCES}

[1] Holland R, van Haelst UJ. Mammary carcinoma with osteoclast-like giant cells. Additional observations on six cases. Cancer 1984;53(9):1963-73.

[2] Cai N, Koizumi J, Vazquez M. Mammary carcinoma with osteoclast-like giant cells: a study of four cases and a review of literature. Diagn Cytopathol 2005;33(4):24651.

[3] Rosen PP. Multinucleated mammary stromal giant cells. A benign lesion that simulates invasive carcinoma. Cancer 1979;44(4):1305-8.

[4] World Health Organization classification of tumours: tumours of the breast and female genital organs. Pathology and genetics of tumours of the digestive system. In: World Health Organization Classification of Tumours. Lyon, France: IARC Press 2003: p. 37-41.

[5] Wargotz ES, Norris HJ. Metaplastic carcinomas of the breast: V. Metaplastic carcinoma with osteoclastic giant cells. Hum Pathol 1990;21(11):1142-50.

[6] Tse GM, Tan PH, Putti TC, et al. Metaplastic carcinoma of the breast: a clinicopathological review. J Clin Pathol 2006;59(10):1079-83.

[7] Oberman HA. Metaplastic carcinoma of the breast. A clinicopathologic study of 29 patients. American Journal of Surgical Pathology 1987;11(12):918-29. 